\title{
Comparative study of regulations of Assisted Reproduction between England, Italy, Norway and Ireland
}

\author{
Amanda de Oliveira Alves ${ }^{1}$, Carolina Pinhol Vieira ${ }^{1}$, Patricia de Azambuja ${ }^{1}$, Maria Lecticia Firpe Penna ${ }^{1 *}$ \\ 'Fundação Mineira de Educação e Cultura - Universidade FUMEC, Faculdade de Ciências Humanas, Sociais e da Saúde, Belo Horizonte, MG, Brazil
}

\begin{abstract}
Objective: To compare the regulations of Assisted Human Reproduction in England, Italy, Norway and Ireland, countries that have a high Human Development Index. Method: Cross-sectional qualitative study of regulations of Assisted Human Reproduction in England, Italy, Norway and Ireland, countries with Human Development Index above 0,8. Results: Italy, England and Norway have specific laws of Assisted Human Reproduction. Ireland is the only one with a Guide of Professional Conduct and Ethics issued by the Federal Council of Medicine of the country. Conclusion: The similar situation of Human Development Index in the studied countries has no influence in the Assisted Human Reproduction regulations.
\end{abstract}

Keywords: human reproduction; laws; regulations; HDI.

\section{Introduction}

In the last years, the world has suffered an astonishing reduction of the fertility rates. This is due to the actual life habits, as cigarettes, alcohol, and obesity and also for the delay of many couples to start a family, increasing the demand for Assisted Human Reproduction ${ }^{1}$ (AHR), but many couple do not benefit from these techniques because they are not available on their country.

The In vitro fertilization (IVF) have begun on England in 1978, with the birth of Louise Brown, ${ }^{2}$ and since then it had a wide dissemination all over the world, what create a blooming development of the AHR and, therefore, a huge variation of fertilization and gametes cryopreservation techniques.

Those improvements increased meaningfully the chances of a pregnancy. However, the biggest challenge has been to make those technical approachable to everyone, without harm any cultural, religious or ethics diversities existent in the different countries. ${ }^{1}$

In Italy, the influence of the catholic religion has an interference on many assisted reproductive processes. ${ }^{3,4}$ In Ireland, apart from the religious aspect, it appears that is a stricter position regarding the embryo's rights to life and the stem cells manipulation, ${ }^{5}$ causing major ethical discussions in the country.

Norway is, according to the United Nations Development Programme (UNDP), ${ }^{6}$ the country with the higher Human Development Index (HDI), and, because of its economic condition, was considered in 2015 by the NGO Save the Children ${ }^{7}$ as the best place in the world for motherhood, what can have an influence in the developments and adaptations on the regulations about AHR in the country.

The present study has as a goal compare the regulations on AHR in England, Italy, Norway and Ireland, Europeans developed countries with similar socioeconomic situations.

Financial support: University FUMEC, Belo Horizonte, MG, Brazil.

Conflicts of interest: The authors declare no conflicts of interest.

Submitted: May 26, 2017.

Accepted: October 31, 2017.

The study was carried out at Department of Biomedical Sciences, College of Human, Social and Health Sciences, University FUMEC, Belo Horizonte, MG, Brazil.

Copyright Alves et al. This is an Open Access article distributed under the terms of the Creative Commons Attribution License, which permits unrestricted use, distribution, and reproduction in any medium, provided the original work is properly cited. 


\section{Metodhology}

A cross-sectional quantitative study was conducted in order to compare different regulations towards the AHR in England, Italy, Norway and Ireland. The criteria to the selection of the countries was to have an HDI above 0,8 and being Europeans.

The study was made by means of searching official information about the regulations on the Medicine Councils and official government departments of the selected countries.

\section{Results}

\section{Italy}

The AHR law in Italy suffered modifications since its original version. The law n40/2004 named "Norme in materia di procreazione medicalmente assistita"s restrain the use of technical of reproduction only when there is confirmed infertility by a doctor, as a way of allow the procreation, being forbidden, under penalty of fine, the use of those technical without its previous contentment. This law forbids: the use of heterologous gametes, the use of surrogacy and the use of the technical for single people. It is also forbidden the fertilization of more than 3 embryos per cycle, and, consequently, it is allowed only the transference of the three embryos, being denied its discard. The cryopreservation of embryos is forbidden, except in situations where the woman's health does not approve the fresh embryo transfer. In this situation, it is approved their cryopreservation for a brief moment, until the transfer is possible. It is authorized the cryopreservation of feminine and masculine gametes. This law also forbids the embryonic reduction and allows the embryos to be used in researches with therapeutic purposes and of diagnoses with the intent of health protection and development of the embryo itself. However, it is forbidden the embryonic selection from their genetic characteristics to non-therapeutic purposes, just as the embryo production only for research.

On May of 2009, the Constitutional Italian Court $\left(n^{0} 151 / 09\right)^{9}$ allowed the medical choice of the number of embryos to be transferred, and limited the number of cryopreserved, prohibiting them to be destroyed or donated.

On April of 2017 the Constitutional Court ${ }^{10}$ authorized the donation of gametes, thus approving the heterologous artificial insemination, with the argument that the previous law violated the right of a couple to constitute a family, the self-determination right and the right to health.

\section{Norway}

The AHR is regulated by the law $n^{0} 100 / 2003^{11}$. It defines that the decision for the utilization of AHR technical is taken by the doctor based on a psychological evaluation of the couple. The law point out that the use of those technical is only allowed if the woman is married or in a stable relationship. The artificial insemination is only authorized if the man is infertile or suffers from some hereditary disease, or, in special cases, if the woman has some hereditary disease related to sex. The donation of masculine gametes is only approved if the donor is a person of legal age, and the child originated from the procedure can know the donor when achieve 18 years old. It is forbidden the fertilization post mortem and the donation of oocytes, or part of them.

It is allowed the cryopreservation of oocytes or ovarian tissue, but it must be discarded in case of the woman's death. The cryopreservation of embryos is authorized for a maximum period of five years, being mandatory the discard after this period. It is forbidden the use of surrogacy, whereas in the law it is written that embryos can only be transferred to the woman from who the oocytes were retrieved. It is only approved to realize pre-implantation genetic diagnoses and select the sex of the embryo in cases of sex related genetic diseases. It is forbidden the use of oocytes, human embryos or cell lineages derived from oocytes or embryos for research purposes.

\section{England}

Nowadays, the law that regulates the AHR in England is the Human Fertilisation and Embryology Act 2008,12 that changed some points of the assisted human fertilization law from $1990 .{ }^{13}$ In both the regulations, the artificial insemination can occur through the donation of homologous and heterologous gametes, not existing obligation of anonymity to this donation. It is allowed the surrogacy with financial payback, being considered the mother the one who realized the gamete donation. The maximum quantity approved to the embryo transfer differs according to the age. The law from 1990 used to support the transfer of 1 or 2 embryos in women aged 35 or under, while the actual, allows the transference of up to two embryos to women aged 40 or under, and above this age it is authorized 3 embryos. The post mortem fertilization is approved, but do not concede successions rights to the child.

The artificial insemination is approved to single women and the law from 2008 added a clause also authorizing the use of this technical for homosexual couples, being considered the father of the child, in the case of masculine homosexual, only the donor of semen. The donation of gametes, in turn, is authorized for both sexes. The cryopreservation is allowed 
for gametes and embryos. The previous law restricted the maximum time that the gametes could be maintained cryopreserved in 10 years, while the new law decreased this limit for 8 years, being that after this time the gametes can be discarded. Despite not fixed in the law, the England utilizes the practice of embryonic reduction when there is some risk to the fetus or to the patient. Lastly, the utilization of gametes to research is allowed and its strictly forbidden the utilization of embryos.

\section{Ireland}

The Ireland does not have a law that regulates the AHR, although there is a conduct guide named Guide to Professional Conduct and Ethics for Registred Medical Practitioners, published by the Medicine Federal Council. The first one was published in $2004^{14}$ and reformulated in $2009^{15}$. It was stipulated in 2004 that the fertilized oocytes must be used to the implantation, and could not be discarded. In 2009, this publication is absent. The donation of embryos was also omitted on the 2009 reformulation. However, the new orientations affirm that the artificial insemination must be realized only for professionals properly qualified, on suitable installations and according to the best international practice, besides having being introduced the criteria that determines that the donation of the gametes must be altruistic and not commercial, observation that was not included on the 2004 guide. The anonymity to cases of heterologous fertilization is still in force.

The conduct guide of 2009 preserved the follow regulations of the previous guide: the use of surrogacy since is not paid, the permission of the gametes and embryos cryopreservation and the use of assisted reproduction techniques for single people. Only the gamete's donor is recognized as the father.

The parameters regarding maximum age assessing these techniques, quantity of embryos to be transferred, fertilization post mortem and embryonic reduction are not described on any of the guides.

\section{Discussion}

The present study intended to compare different European countries inside the same $\mathrm{HDI}^{6}$ in relation to their regulations on AHR (Table 1).

After the analysis were observed similarities and differences among the countries in question. In all the countries analyzed it is allowed the realization of homologous and heterologous fertilization..$^{10-15}$ The anonymity of the heterologous fertilization is required only in Ireland, ${ }^{14,15}$ although some clinics use the gametes of a known donor, ${ }^{16}$ as realized in

Table 1. HDI from England, Ireland, Italy and Norway

\begin{tabular}{ccccc}
\hline & England & Ireland & Italy & Norway \\
\hline IDH & 0.892 & 0.899 & 0.872 & 0.944 \\
\hline
\end{tabular}

England. ${ }^{12,13}$ In Norway, ${ }^{11}$ the people generated from the AHR technologies can contact their donor after the age of 18. On the other hand, in Italy, the anonymity is not described by law, ${ }^{8-10}$ the doctor being the responsible over the decision of using a known donor or not. The donation of gametes is approved in all the countries studied, except in Norway, ${ }^{11}$ that restrict the donation only to masculine gametes.

The utilization of surrogacy is not legalized in Italy ${ }^{8-10}$ and Norway ${ }^{11}$, meanwhile it is consented in Ireland ${ }^{14,15}$ and in England, ${ }^{12,13}$ one of the only countries in the world that accept the payment for the use of this technique. The quantity of embryos to be transferred is not described in Ireland ${ }^{14,15}$ and in Norway. ${ }^{11}$ In England the quantity is specified according to the age of the woman ${ }^{12,13}$ and in Italy and it is a medical decision ${ }^{9}$ that can generate the occurrence of an undesired multiple pregnancy (Table 2)

There was no regularized maximum age to the realization of AHR in Ireland, Norway and England, turning accessible the utilization of the technical for woman over the fertility age, even when those present small chances of success in treatment. In Italy, the maximum age allowed to the transfer is defined as the fertililty age. ${ }^{8}$

Among the studied countries, England is the only that authorizes legally the fertilization post mortem. ${ }^{12,13}$ The realization of fertilization techniques in single people is authorized only in Ireland ${ }^{14,15}$ and in England only in women. ${ }^{12,13}$ In the case of homosexual couples the England approves the use of the reproductive techniques to both sexes ${ }^{12,13}$ and Norway only to female homosexuals, ${ }^{11}$ due to the prohibition of surrogacy in the country, what makes impracticable the use of the technical to masculine couples. In Italy, the practice is forbidden because of the religious influence of the Catholicism that has conservatives opinions towards the assisted reproduction and new family compositions. ${ }^{3}$ 
Table 2. Assisted Human Reproduction (RHA) Regulations in England, Ireland, Italy and Norway

\begin{tabular}{|c|c|c|c|c|}
\hline & England & Ireland & Italy & Norway \\
\hline Types of fertilization & $\begin{array}{l}\text { Homologous and } \\
\text { heterologous }\end{array}$ & $\begin{array}{l}\text { Homologous and } \\
\text { heterologous }\end{array}$ & $\begin{array}{l}\text { Homologous and } \\
\text { heterologous }\end{array}$ & $\begin{array}{l}\text { Homologous and } \\
\text { heterologous }\end{array}$ \\
\hline $\begin{array}{l}\text { Preservation of the donor's anonymity in } \\
\text { heterologous fertilization }\end{array}$ & No & Yes & Not described in law & No, after 18 years \\
\hline Surrogacy & Yes & Yes & No & No \\
\hline Age limit & Not described in law & Not described in law & Fertile age & Not described in law \\
\hline Number of embryos to transfer & $\begin{array}{l}\text { Up to } 40 \text { years: } 1 \text { or } 2 \\
\text { Over } 40 \text { years: } 3\end{array}$ & Not described in law & At medical discretion & Not described in law \\
\hline Post mortem reproduction & Yes & Not described in law & No & No \\
\hline Couples in homoaffective union & Yes & Not described in law & No & $\begin{array}{l}\text { Only female } \\
\text { homoaffective union }\end{array}$ \\
\hline Singles (marital status) & Yes, women & Yes & No & No \\
\hline Gamete donation & Yes & Yes & Yes & $\begin{array}{l}\text { Semen: Yes } \\
\text { Oocyte: No }\end{array}$ \\
\hline $\begin{array}{c}\text { Cryopreservation of gametes and } \\
\text { embryos }\end{array}$ & Yes & Yes & $\begin{array}{l}\text { Gametes: Yes } \\
\text { Embryos:No }\end{array}$ & Yes \\
\hline Pre-implantation genetic diagnosis (PGD) & Yes & Yes & Yes & Yes \\
\hline Sex selection for non-medical reasons & No & No & No & No \\
\hline Embryo discarding & Yes & No & No & Yes \\
\hline Embryonic reduction & Not described in law & Not described in law & No & Not described in law \\
\hline Use of embryos for research & No & Not described in law & No & No \\
\hline
\end{tabular}

A parameter that deserves bigger discussions is the embryonic reduction that is not allowed in Italy ${ }^{8}$ and is not described in other countries. Nowadays, what is observed is the tendency to transfer a smaller number of embryos, due to the hihj quality, taking to a high rate of pregnancy.

The cryopreservation of the gametes and embryos is authorized in England, ${ }^{12,13}$ Ireland ${ }^{14,15}$ and Norway. ${ }^{11}$ In Italy is permitted only the cryopreservation of the gametes, except in cases where the health of the woman does not approve the transference in a fresh cycle, ${ }^{8,9}$ once the Catholicism believes that the freezing injures the embryo and consequently, the human life. ${ }^{4}$ The discard of embryos, in turn, is only allowed in England and Norway. ${ }^{11,12}$

The realization of the pre-implantation diagnoses is authorized in all the countries studied, in order to select for the transfer the embryos that are not carrier of hereditary diseases or linked to the sex. However, the selection of the sex for not medical reasons is categorically forbidden for ethical reasons in all the countries studied. It is not legalized neither the use of embryos and gametes in research, what delays the development of pursuit for greater knowledge towards AHR. In England is allowed the utilization of gametes only for scientific purposes.

\section{Conclusion}

The country with the greater acceptance to the reproductive techniques is England, what was already expected once it is the pioneer of assisted reproduction techniques worldwide and to be the country with more technological breakthroughs in this area. More recently, for example, the "3 parent embryo", that allows the embryo to be fertilized with the DNA of three people, being the genetic material of the father, the mother and the mitochondrial DNA of a donor ${ }^{17}$.

Norway, although is the country with the higher HDI it is not the most developed in relation to the AHR, and the title of "best place in the world for motherhood" does not have any influence in the laws that manage the country.

Ireland does not have any regulations in the constitution of the AHR; even so, there is a conduct guide that is very unsteady, creating a need of a creation of a law or wide regulation. 
Italy, because of a strong religious influence has a more restrict law, respecting the conservatives opinions of the Catholicism towards the way to conceive a family. ${ }^{3,4}$

In resume, it is possible to highlight that the similar situation of the HDI of the studied countries does not have any influence over the current regulations on Assisted Human Reproduction.

\title{
References
}

1. SOUZA MCB, DECAT DE MOURA M, GRYNSZPAN D, organizers. Vivências em tempo de reprodução assistida: o dito e o não-dito. Rio de Janeiro: Revinter; 2008.

2. KAMEL RM. Assisted Reproductive Technology after the Birth of Louise Brown. J Reprod Infertil. 2013;14(3):96-109. PMid:24163793.

3. JONES HW Jr, CROCKIN SL. On assisted reproduction, religion, and civil law. Fertil Steril. 2000;73(3):447-52. PMid:10688994. http:// dx.doi.org/10.1016/S0015-0282(99)00542-7.

4. Donum Vitae. Instruction on respect for human life in its origin and on the dignity of procreation replies to certain questions of the day [Internet]. 1982 [cited 2017 May 26]. Available from: www.vatican.va/roman_curia/congregations/cfaith/documents/ rc_con_cfaith_doc_19870222_respect-for-human-life_en.html

5. ALEMU C. Como regulamentar as biotecnologias? [Internet]. [cited 2017 May 26]. Available from: http://www.ambafrance.org.br/ abr/label/label49/dossier/07.html

6. Programa das Nações Unidas para o Desenvolvimento [Internet]. Brasília: PNUD [cited 2017 May 26]. Available from: http://www. pnud.org.br/

7. Save the Children. The complete mothers' index 2015 [Internet]. 2015 [cited 2015 May 20]. Available from: http://www.savethechildren. org/atf/cf/\%7B9def2ebe-10ae-432c-9bd0-df91d2eba74a\%7D/SOWM_MOTHERS_INDEX.PDF

8. Repubblica Italiana. Parlamento Italiano. Legge 19 febbraio 2004, n. 40. Norme in materia di procreazione medicalmente assistita. Gazzetta Ufficiale [Internet]; Rome; 2004 Feb 24 [cited 2015 Set 30]. Available from: http://www.camera.it/parlam/leggi/04040l.htm

9. Repubblica Italiana. Corte Constituzionale. Sentenza n. 151 anno 2009. Gazzetta Ufficiale [Internet]; Rome; 2009 May 13 [cited 2015 Set 25]. Available from: http://www.cortecostituzionale.it/actionSchedaPronuncia.do?anno=2009\&numero=151

10. BALDINI G. Fecondazione eterologa: incostituzionale il divieto della Legge 40 [Internet]. Milano: Altalex; 2014 [cited 2015 Set 23 ]. Available from: http://www.altalex.com/documents/news/2014/06/19/fecondazione-eterologa-incostituzionale-il-divieto-della-legge-40

11. Norway. Act of 5 December 2003, no. 100. Relating to the application of biotechnology in human medicine, etc [Internet]. Noruega; 2003 [cited 2015 Ago 30 ]. Available from: https://www.regjeringen.no/globalassets/upload/kilde/hod/red/2005/0081/ddd/pdfv/242718biotechnology_act_master.pdf

12. England. Legislation UK. Human Fertilisation and Embriology act 2008 [Internet]. Inglaterra: The Stationery Office Limited; 2008 [cited 2015 Set 28]. Available from: http://www.legislation.gov.uk/ukpga/2008/22/contents

13. England. Legislation UK. Human Fertilisation and Embriology Act 1990 [Internet]. Inglaterra: The Stationery Office Limited; 1990 [cited 2015 Set 28]. Available from: http://www.legislation.gov.uk/ukpga/1990/37/contents?view=plain

14. WALSH DJ, MA ML, SILLS ES. The evolution of health policy guidelines for assisted reproduction in the Republic of Ireland, 20042009. Health Res Policy Syst. 2011;9(1):28. PMid:21702949. http://dx.doi.org/10.1186/1478-4505-9-28.

15. Ireland. Medical Concil. The guide to Professional Conduct \& Ethics for Registered Medical Practitioners. Dublin; 2009 [cited 2015 Set 15]. Available from: http://www.medicalcouncil.ie/News-and-Publications/Publications/Professional-Conduct-Ethics/Guide-toProfessional-Conduct-and-Behaviour-for-Registered-Medical-Practitioners-pdf.pdf

16. Ireland. Commission on assisted Human Reproduction. Report of the Commission on Assisted Human Reproduction. Irlanda; 2005 [cited 2015 Set 15]. Available from: http://www.lenus.ie/hse/bitstream/10147/46684/1/1740.pdf

17. GALLAGHER J. UK approves three-person babies. BBC News; 2015 Fev 24 [cited 2015 Out 2]. Available from: htttp://www.bbc.com/ news/health-31594856

\author{
*Correspondence \\ Maria Lectícia Firpe Penna \\ Rua Cobre, 200, Cruzeiro \\ CEP 30310-190, Belo Horizonte, MG, Brazil \\ E-mail: mlpenna@fumec.br
}

\section{Authors information}

AOA and CPV - Bachelor in Biomedicine, Department of Biomedical Sciences, College of Human, Social and Health Sciences, University FUMEC. PA - Specialist Teacher, Department of Biomedical Sciences, College of Human, Social and Health Sciences, University FUMEC. MLFP - Doctor teacher Department of Biomedical Sciences, College of Human, Social and Health Sciences, University FUMEC.

\section{Authors contribution}

AOA research, discussion and writing of the text. CPV research, discussion and writing of the text. PA research, discussion and writing of the text. MLFP orientation of the study, research, discussion, writing and review of the text. 